\title{
'wtf is Barbara?'
}

James Morrow

Katholische Universität Eichstätt-Ingolstadt

During the Second World War the phrase 'KILROY WAS HERE' was often found scribbled on objects and walls throughout Europe. It was on cargo ship hulls, airplane fuselages, railcars, cathedrals, the Arc de Triomphe, and it even appeared on road signs near concentration camps. There is a legend that it made its way onto the wall of Stalin's private toilet at the Potsdam Conference. And there is another that Hitler was convinced it was some sort of code shared by allied spies. ("Transit Association Ships a Street Car to Shelter Family of 'Kilroy Was Here"', New York Times, 24 December 1946)

'KILROY WAS HERE' even went global and started to procreate. There was an Australian compatriot called 'FOO'. Likewise, 'CHAD' made appearances in the Middle East, India, Burma, and Singapore. (Elizabeth Reeve, 'Wot! Chad's Here', Life, 18 March 1946, 18-23, Print)

After the war, 'KILROY WAS HERE' lived-on in literature. The phrase appears in Thomas Pynchon's $V$. The main character in Isaac Asimov's 'The Message' is George Kilroy, a timetravelling graffiti artist. Even the master of American Southern style, William Faulkner, joked that 'KILROY' was the spirit of an artist:

The aim of every artist is to arrest motion, which is life, by artificial means and hold it fixed so that a hundred years later, when a stranger looks at it, it moves again since it is life. Since man is mortal, the only immortality possible for him is to leave something behind him that is immortal since it will always move. This is the artist's way of scribbling "Kilroy was here" on the wall of the final and irrevocable oblivion through which he must someday pass. (William Faulkner, interview by Jean Stein, Paris Review, Spring 1956, Print)

In Berlin Mitte, posters have recently appeared that quote somebody called Barbara. One says 'Barbara war hier. Und alle so: „wtf is Barbara?” [Barbara was here. And everybody is like: 'wtf is Barbara?']. Another reads: 'Niemand hat die Absicht ein Plakat anzukleben' [Nobody has the mind to post handbills]. 

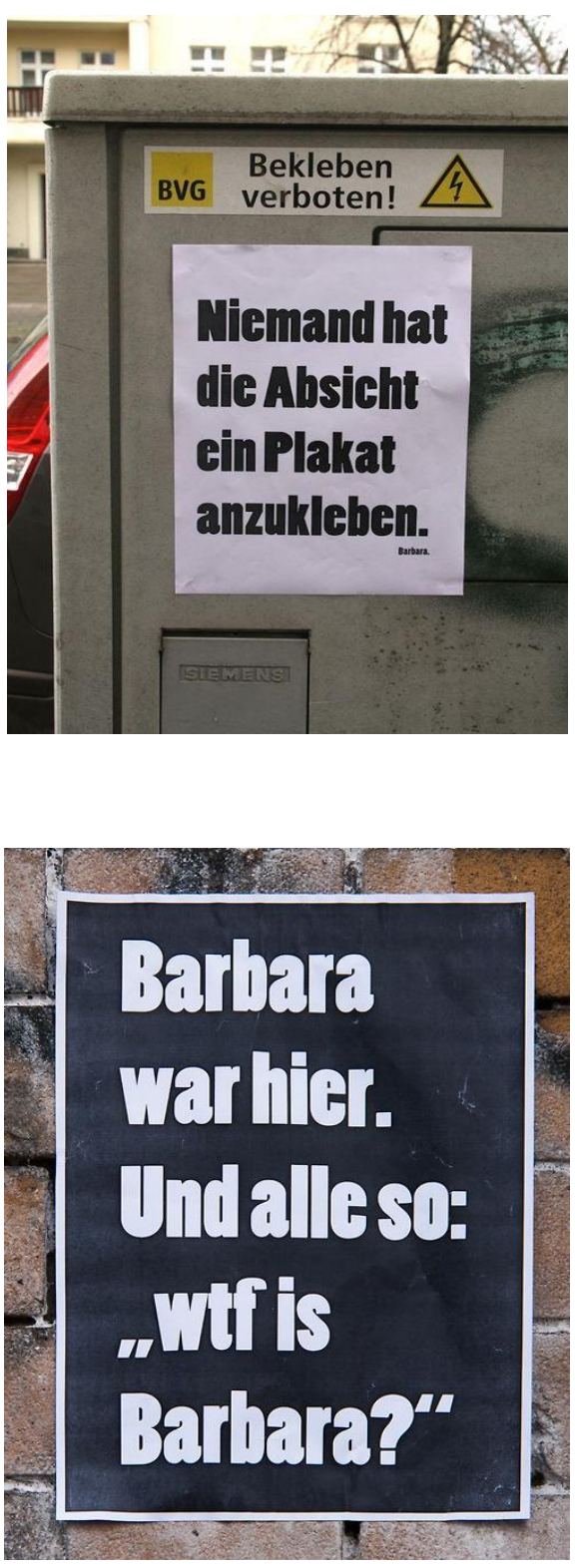

'wtf is Barbara?'

In Berlin, it is not uncommon to see handbills quoting famous philosophers. Quotes from Buddha, Gandhi, Tagore, and Rumi are common. Sometimes there may be a line from Brecht or Goethe. But Barbara is not a well-known philosopher. There are no books by or about Barbara. And Barbara does not even have a Wikipedia entry. More importantly, it is not known who or what Barbara is.

It is more likely that Barbara is like a spiritual progeny of KILROY. Barbara is the spectral philosopher of the street. Barbara, like Faulkner says, is an artist who seeks to 'arrest motion' and avoid oblivion by posting a few words to mark their place in the world. 
TranscUlturAl, vol. 6.1 (2014), 53-55.

http://ejournals.library.ualberta.ca/index.php/TC

\section{REFERENCES}

Faulkner, William. Interview by Jean Stein. Paris Review, Spring 1956.

Reeve, Elizabeth. 'Wot! Chad's Here'. Life. 18 March 1946. 18-23.

"Transit Association Ships a Street Car To Shelter Family of 'Kilroy Was Here'." New York Times. 24

December 1946. 